\title{
The Return from Organic to Inorganic Carbon
}

Almost all the organic matter produced is eventually consumed and respired to inorganic carbon because organic matter preservation via burial in accumulating sediments $\left(\sim 0.2-0.4 \mathrm{Pg}^{-1}\right)$ represents only a very small fraction of that produced. Global phytoplankton production is about $\sim 50 \mathrm{Pg} \mathrm{C} \mathrm{y}^{-1}$, while phytoplankton biomass is $\sim 1 \mathrm{Pg}$, implying a turnover of one week $\left(0.02 \mathrm{y}^{-1}\right)$. Marine macrophytes have a similar global biomass, but a production of only $1 \mathrm{Pg} \mathrm{C} \mathrm{y}^{-1}$; the turnover is thus $\sim 1 \mathrm{y}^{-1}$ (Smith 1981). These high turnover rates (compared with global terrestrial vegetation turnover of about one to two decades, Field et al. 1998) imply not only steady production, but also efficient consumption of organic matter. There are multiple organic matter loss pathways (respiration by autotrophs and heterotrophs, grazing, viral lysis, detrital route), but all eventually result in respiration and release of inorganic carbon.

Biogeochemists constructing carbon budgets normally lump together the various organic matter loss pathways and focus instead on the quantification of the organic carbon to inorganic carbon transformation. However, for a more detailed understanding, the elucidation of the link with other biogeochemical cycles and the identity of organisms involved, the various pathways have to be resolved. Before discussing the processes and mechanisms involved in these routes, it is instructive to distinguish between living organic matter that has the capability to reproduce (primary and secondary producers) and dead organic matter (i.e. detritus). While living organic matter is, by definition, fresh and thus labile, detrital organic matter pools represent a heterogeneous mixture of compounds from various sources which have been mixed together and which may have distinct compositions, degradation histories and reactivities (Box 3.1). Another distinction is between organic matter in the dissolved and particulate phases. Concentrations of DOC (order 10$100 \mathrm{mmol} \mathrm{m}^{-3}$ ) are usually one order of magnitude higher than those of POC (order $1-10 \mathrm{mmol} \mathrm{m}^{-3}$ ) in the euphotic zone of the ocean, while sediment POC (order $10^{6} \mathrm{mmol} \mathrm{m}^{-3}$ ) concentrations are normally three orders of magnitude higher than those of DOC in pore water (100-1000 $\mathrm{mmol} \mathrm{m}^{-3}$ ). Moreover, the DOC pool is detrital (with viruses), while the particulate organic carbon pool usually 
represents a mixture of living organisms, their remains, and other detrital organic carbon inputs. As we discussed in Chap. 2, the POC concentrations in the water column can be a poor proxy for phytoplankton carbon. This distinction between dissolved and particulate pools is pivotal for understanding the fate of organic matter. Dissolved organic matter is transported as a solute with the water, while particulate organic matter is subject to gravity, which results in settling of organic particles. Consequently, the residence time of DOC in an aquatic system is much longer than that of POC. Consumption of dissolved organic matter primarily involves microbes and other small organisms, which use it for energy and nutrient acquisition, while larger organisms generally prefer particulate organic matter. Microbes use extracellular enzymes to solubilize particulate organic matter before they can utilize it.

In this chapter, we discuss carbon consumption in the context of the "biological pump". The latter depends on the fraction of primary produced organic matter that survives degradation in the euphotic zone and that is exported from surface water to the ocean interior, where it mineralized to inorganic carbon, with the result that carbon is transported against the gradient of dissolved inorganic carbon from the surface to the deep ocean. This transfer occurs through physical mixing and transport of dissolved and particulate organic carbon, vertical migrations of organisms (zooplankton, fish) and through gravitational settling of particulate organic carbon (Volk and Hoffert 1985; Sarmiento and Gruber 2006). We first discuss carbon consumption pathways in the euphotic zone, then the factors governing export of organic carbon from the euphotic zone and particle degradation in the ocean interior. Processes specifically related to organic carbon consumption in the coastal zone are presented in Box 3.2.

\subsection{Carbon Consumption Pathway in the Euphotic Zone}

For pelagic ecosystems, Legendre and Rassoulzadagan (1995) proposed a continuum of trophic pathways with the herbivorous food-chain and microbial loop as food-web end members (Fig. 3.1). The classical linear food-chain end-member involves grazing by zooplankton on larger phytoplankton and subsequent predation on zooplankton by either larger zooplankton or another predator. In such a linear food-chain a predator can either lead to high phytoplankton biomass (in a system with phytoplankton, herbivore and a predator) or reduced phytoplankton biomass (in a system with four levels). Changes in predator abundance can, thus, lead to trophic cascades (Pace et al. 1999). The microbial loop end-member involves not only phytoplankton, as basal resource, but also dissolved organic carbon (Azam et al. 1983). Dissolved organic carbon is used by heterotrophic bacteria for growth and respiration, and these heterotrophic bacteria are, in turn, consumed by microzooplankton (20-200 $\mu \mathrm{m}$; ciliates, radiolarian, foraminifera) that are predated upon by larger zooplankton. Consequently, dissolved organic carbon is transformed, via a bacterial-microzooplankton loop, to zooplankton. These two end-member carbon 
processing pathways are connected at multiple levels. Small phytoplankton can be consumed directly by microzooplankton. Dissolved organic carbon is produced in multiple ways and by various organisms, both by primary producers and consumers of organic carbon (Fig. 3.1). DOC release by primary producers occurs passively by leakage and actively during unbalanced growth during nutrient limitation (Anderson and LeB Williams 1998; Van den Meersche et al. 2004). Another direct pathway from phytoplankton to dissolved organic pool involves viral lysis (Suttle 2005). Viruses are a major cause of phytoplankton mortality in the ocean, particularly in warmer, low-latitude waters. Sloppy feeding by herbivores and incomplete digestion of prey by consumers are other sources of dissolved organic carbon. Heterotrophic microbes use extracellular enzymes to solubilize particulate organic carbon and use this and other dissolved organic carbon resources for growth and maintenance. Part of the microbial heterotrophic production is used by microzooplankton; another part of the heterotrophic community is subject to intense viral lysis and this causes release of dissolved organic carbon again. The efficiency of the microbial loop depends on multiple factors but in particular on the relative importance of predation and viral lysis to the mortality of heterotrophic microbes.

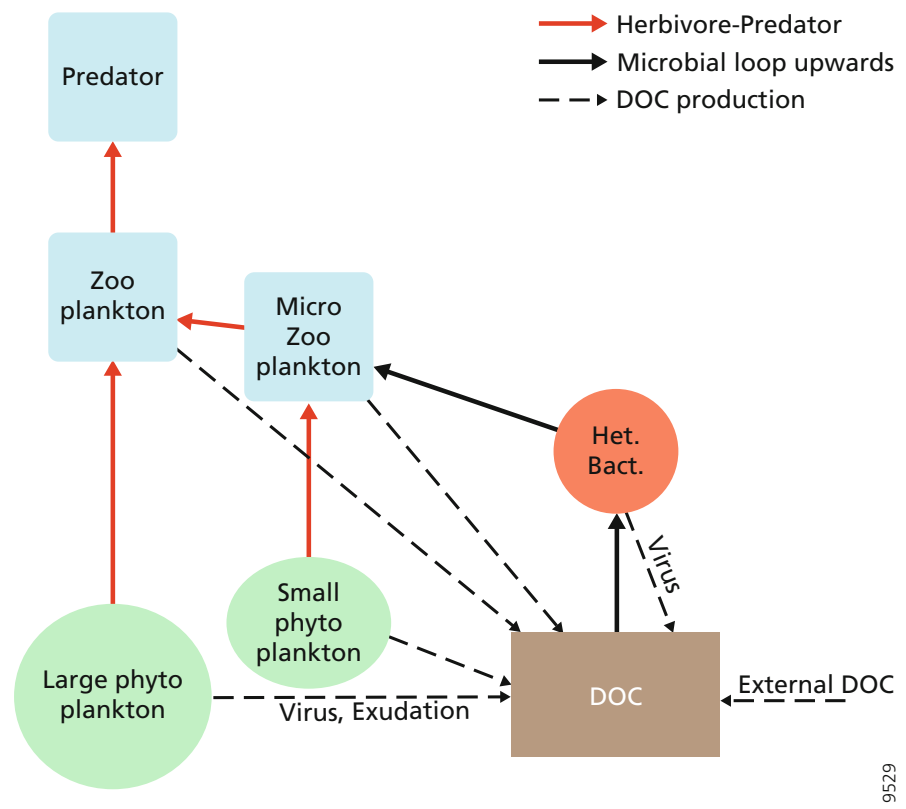

Fig. 3.1 Conceptual diagram of food web structure in euphotic zone. The linear food chain large phytoplankton-herbivore-predator (on the left with red arrow connections) has fewer levels than one with small phytoplankton at the base. The microbial loop refers to the flow from the dissolved organic carbon (DOC) via heterotrophic bacteria (Het. Bac.) and microzooplankton to predatory zooplankton (on the right with black solid arrows). Viruses play a major role in the mortality of phytoplankton and heterotrophic bacteria, and recycle organic carbon back to the DOC pool. Other sources of dissolved organic carbon (also dashed black arrows) includes exudation, sloppy feeding, etc. Particulate detritus pools and fluxes are not shown for simplicity 


\subsection{Factors Governing Export of Organic Matter}

While net primary production (gross production minus respiration by the autotrophs) as presented in Chap. 2 is the property of interest for structure and functioning of food webs in the surface ocean, new and export production are most relevant for the functioning of deep-sea and sedimentary ecosystems and the role of the ocean in the global carbon cycle (Fig. 3.2). New production, also known as net community or ecosystem production, refers to net primary production minus the consumption of organic carbon by heterotrophs in the euphotic zone. At steady state, this new production should be the same as what is exported, i.e. export production. During periods of phytoplankton blooms new production may temporarily exceed export out of the euphotic zone, while rates of export are temporarily higher than new production during the senescence of phytoplankton blooms.

The relations between export, new and net primary production are often expressed in ratios. The e-ratio is defined as:

$$
e-\text { ratio }=\frac{\text { export production }}{\text { net primary production }}
$$

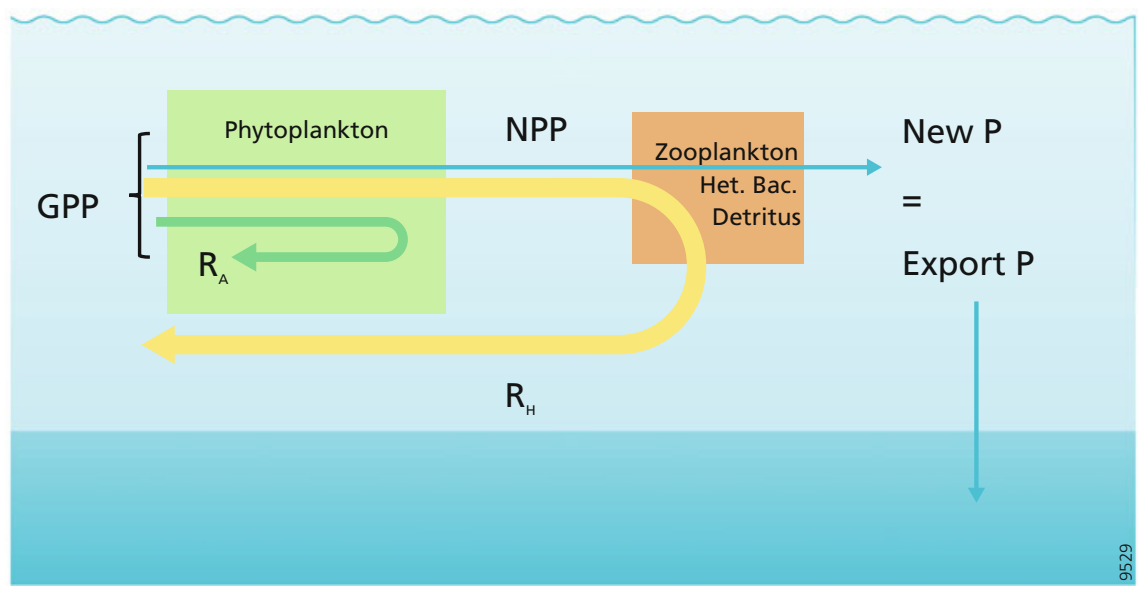

Fig. 3.2 The various types of productivity in the ocean. GPP (gross primary production) is the total rate of carbon fixation/oxygen release by phytoplankton. Part of the GPP is used for autotrophic respiration $\left(\mathrm{R}_{\mathrm{A}}\right)$ by the phytoplankton community, the other part represents net primary production (NPP). The organic matter produced is consumed by heterotrophs for growth and respiration $\left(\mathrm{R}_{\mathrm{H}}\right)$ and the remaining organic matter is new and available for export (NEP, new production, export production). The net primary production (NPP) is most relevant for euphotic zone food web functioning, while the export production is relevant for the biological pump and fuelling deep-sea and benthic food webs. The export or e-ratio divides export/new production by net primary production (NEP/NPP) 
where export production is often quantified via the use of sediment traps (Suess 1980). Note that e-ratios based on sediment trap might be biased if dissolved organic matter is transported downwards by advection and/or eddy-diffusion and if zooplankton and other mobile vertical migrating organism contribute significantly to the total downward flux of organic carbon. An alternative method to quantify the relative importance of new to total production is the f-ratio, based on nitrogen use and recycling:

$$
f-\text { ratio }=\frac{\text { new production }}{\text { new production }+ \text { recycled production }}
$$

where new production is assumed to equal nitrate uptake and recycled production is taken equal to ammonium uptake as determined from ${ }^{15} \mathrm{~N}$ tracer experiments (Dugdale and Goering 1967). The rationale is that nitrogen availability limits primary production, that nitrate is supplied to the euphotic zone from deeper waters (thus new to euphotic zone) and that recycling of organic nitrogen within the euphotic zone generates ammonium. Export of organic nitrogen should eventually, on the global scale, be equivalent to nitrate supply from the deep to surface ocean. However, nitrification (ammonium oxidation to nitrite and nitrate) in the euphotic zone, atmospheric deposition, nitrogen fixation and other nitrogen cycling processes (bacterial uptake of dissolved inorganic nitrogen, dissolved organic nitrogen generation and use) complicate this simple depiction. At steady state e and f-ratios should be the same if the underlying assumptions are correct.

These export ratios vary from $\sim 0.04$ to $\sim 0.72$. Although multiple factors contribute to this range in export ratios (phytoplankton size, community structure, e.g. see Fig. 3.1), temperature and total primary production together account for $87 \%$ of the variance in export production and ratios (Laws et al. 2000, 2011; Dunne et al. 2005). The empirical model of Laws et al. (2011):

$$
e-\text { ratio }=0.04756\left(0.78-\frac{0.43 T}{30}\right) P^{0.307}
$$

shows that e-ratios depend negatively on temperature ( $T$, in Celsius) and scale with the power $\sim 0.3$ to net primary production $(\mathrm{P})$. Export production consequently scales to net primary production with a power of $\sim 1.3$. Temperature is the single most important factor (Fig. 3.3), because organic carbon consumption by heterotrophs is more temperature sensitive than light and nutrient-limited primary production by phytoplankton (Laws et al. 2000). The impact of primary production on the export ratio can be explained by the increase in the size (and thus settling rate) of phytoplankton with increasing primary production (Dunne et al. 2005). The global average export ratio is $\sim 0.2$ with eutrophic, high-latitude systems having high e-ratios and oligotrophic, low-latitude systems having the lowest ratios. 


\subsection{Particulate Organic Carbon Fluxes in Ocean Interior}

The efficiency of the biological pump depends not only on the rate of primary production (Chap. 2), the efficiency of carbon consumption within and export out of the photic zone (Fig. 3.3), but also on the depth at which the organic carbon is respired, because this determines the period during which carbon will be removed from the atmosphere (Yamanaka and Tajika 1996).

This pivotal role of carbon transfer to and within the ocean interior has stimulated observational programs to measure particle fluxes using sediment traps. Suess (1980), Pace et al. (1987) and Martin et al. (1987) were among the first to explore such sediment trap data for the global ocean, and they observed a steady decline of organic carbon fluxes with depth because of degradation during settling (Fig. 3.4a). The empirical open ocean composite from Martin et al. (1987) is most often used:

$$
F_{z}=F_{z_{0}}\left(\frac{z}{z_{0}}\right)^{-b}
$$

where $\mathrm{z}$ is water depth $(\mathrm{m}), \mathrm{z}_{0}$ is the reference level for export (e.g., bottom of the euphotic zone), $\mathrm{F}_{\mathrm{z} / \mathrm{z}_{0}}$ are the fluxes of organic carbon $\left(\mathrm{mol} \mathrm{m}^{-2} \mathrm{~d}^{-1}\right)$ at depths $\mathrm{z}$ and $\mathrm{z}_{0}$, and $\mathrm{b}$ is a fitted coefficient with a value of 0.858 . Although we have made much

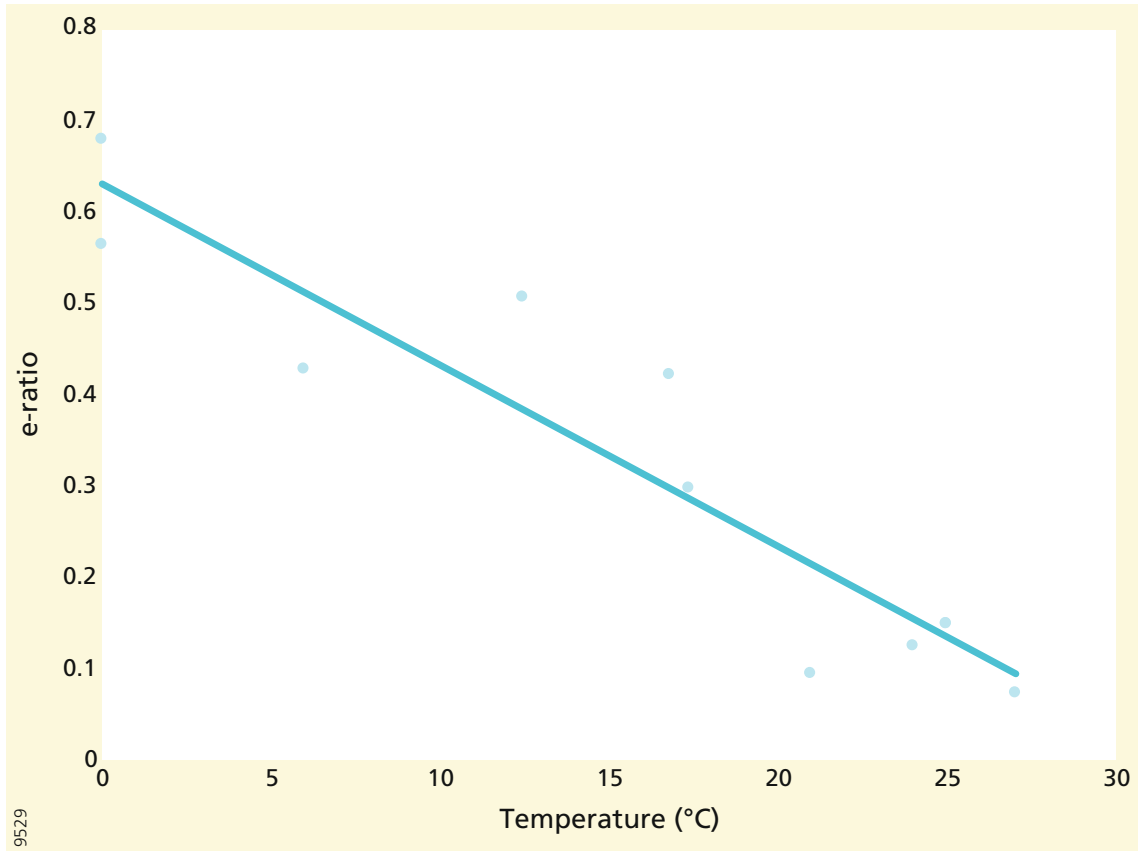

Fig. 3.3 Relation between e-ratio (export production over net primary production) as a function of water temperature (Data compiled by Laws et al. 2000) 


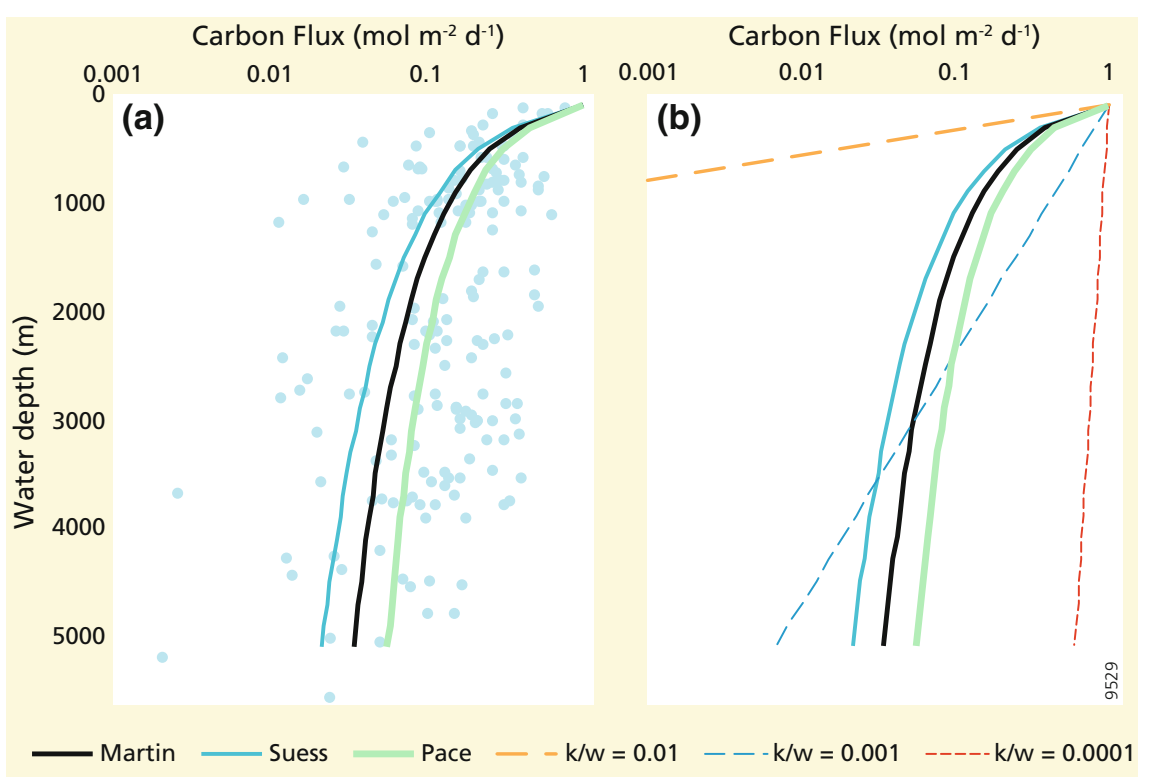

Fig. 3.4 a Fluxes of particulate organic carbon in the ocean interior based on the Martin et al. (1987), Suess (1980) and Pace et al. (1987) relations and data compiled by Lutz et al. (2002). Note that $\mathrm{F}_{\mathrm{z}_{0}}$ has different meanings for the original equations but has been normalized to 1 for this plot. b Fluxes of particulate organic carbon in the ocean interior based on the Martin et al. (1987), Suess (1980) and Pace et al. (1987) relations and exponential curves with attenuation coefficient of 0.01, 0.001 and $0.0001\left(\mathrm{~m}^{-1}\right)$. Martin et al.: $\mathrm{F}_{\mathrm{z}}=\mathrm{F}_{\mathrm{z}_{0}}\left(\frac{\mathrm{z}}{\mathrm{Z}_{0}}\right)^{-0.858}$. Suess: $\mathrm{F}_{\mathrm{z}}=\frac{\mathrm{F}_{\mathrm{z}_{0}}}{(0.0238 \mathrm{Z}+0.212)}$. Pace et al.: $\mathrm{F}_{\mathrm{z}}=\mathrm{F}_{\mathrm{z}_{0}} 3.523 \mathrm{z}^{-0.734}$

progress in our understanding of the governing processes, the basic early findings have not been falsified. The open ocean composite from Martin et al. (1987) is used in many earth system and ocean biogeochemical models. The parameter $b$ typically ranges from 0.6 to 1.3 , with lower values in low oxygen settings and higher values in productive high-latitude systems (Berelson 2001). This variance in b values has been attributed to community structure, oxygen, temperature and mineral ballasting. Alternative more complex formulations have been derived.

To understand the factors governing particulate organic matter fluxes in the ocean interior, we will introduce a simple model for POC fluxes. At any water depth ( $\mathrm{z}$, directed downwards) below the export reference level $\left(\mathrm{z}_{0}\right)$, the particulate organic carbon concentration is governed by the balance of particulate organic matter supply by settling particles and degradation:

$$
w \frac{d P O C}{d z}=-k P O C
$$


where $\mathrm{w}$ is the settling velocity $\left(\mathrm{m} \mathrm{d}^{-1}\right)$, POC is the concentration of particulate organic carbon $\left(\mathrm{mol} \mathrm{m}^{-3}\right)$ and $\mathrm{k}$ is a first-order rate constant $\left(\mathrm{d}^{-1}\right)$. Assuming a constant first-order rate constant $\mathrm{k}$ (i.e. one-G model; Box 3.1), a constant settling rate $(\mathrm{w})$, and a known export flux of organic carbon at the reference depth $\left(\mathrm{F}_{\mathrm{z}_{0}}\right)$ the solution is an exponential:

$$
P O C_{z}=\frac{F_{z_{0}}}{w} e^{\frac{-k}{w}\left(z-z_{0}\right)}
$$

Moreover, $F_{z}=P O C_{z} w$ because $\mathrm{w}$ is constant, and thus, the flux of particulate organic carbon is given by:

$$
F_{z}=F_{z_{0}} e^{\frac{-k}{w}\left(z-z_{0}\right)}
$$

Accordingly, vertical organic carbon fluxes in the ocean are expected to decline exponentially with water depth and the attenuation is governed by the ratio between the organic matter degradation rate constant $k$ and particle settling velocity $w$.

Figure 3.4b presents the Suess, Pace and Martin curves again but now together with three curves based on the exponential mechanistic model with $\mathrm{k} / \mathrm{w}$ values varying from high attenuation (0.01) to very low attenuation (0.0001). While none of these can describe the observations, the former agrees with the upper part, while the latter agrees with the lower part. This was already noted by Martin et al. (1987) and implies that the assumption of constant $\mathrm{k}$ and/or $\mathrm{w}$ is likely not correct.

If our assumption of constant $\mathrm{k}$ is the main and only reason, then we would expect much improvement in model prediction with a multi-G or reactive continuum model (see Box 3.1). Figure 3.5 presents model predictions for both a multi-G and reactive continuum model based on model parameters for the phytoplankton decay experiments of Westrich and Berner (1984), presented by Boudreau and Ruddick (1991). While accounting for a decreasing reactivity of organic matter with depth improves the model performance in the upper part, there is still a large discrepancy at depth. However, better agreement can be obtained by fitting rather than imposing the organic matter degradation rate parameters based on literature values. The resulting gamma shape parameter $(v>0.6$, depending on sinking velocity w chosen) is within the range of reported values (Arndt et al. 2013). Such a high $v$ implies that settling organic matter is dominated by labile fractions, which seems reasonable.

Alternatively, the particle sinking velocity may be a function of water depth. Particle sinking velocity (w) is governed by Stokes' law:

$$
w=\frac{2 g r^{2} \Delta \rho}{9 \mu}
$$

where $g$ is the gravitational acceleration $\left(9.81 \mathrm{~m}^{2} \mathrm{~s}^{-1}\right), \mathrm{r}$ is the particle radius $(\mathrm{m})$, $\Delta \rho$ is the density difference between seawater and the particle $\left(\mathrm{kg} \mathrm{m}^{-3}\right)$ and $\mu$ is the dynamic viscosity of water $\left(\mathrm{N} \mathrm{s} \mathrm{m}^{-2}\right)$. In other words, particle settling is governed 


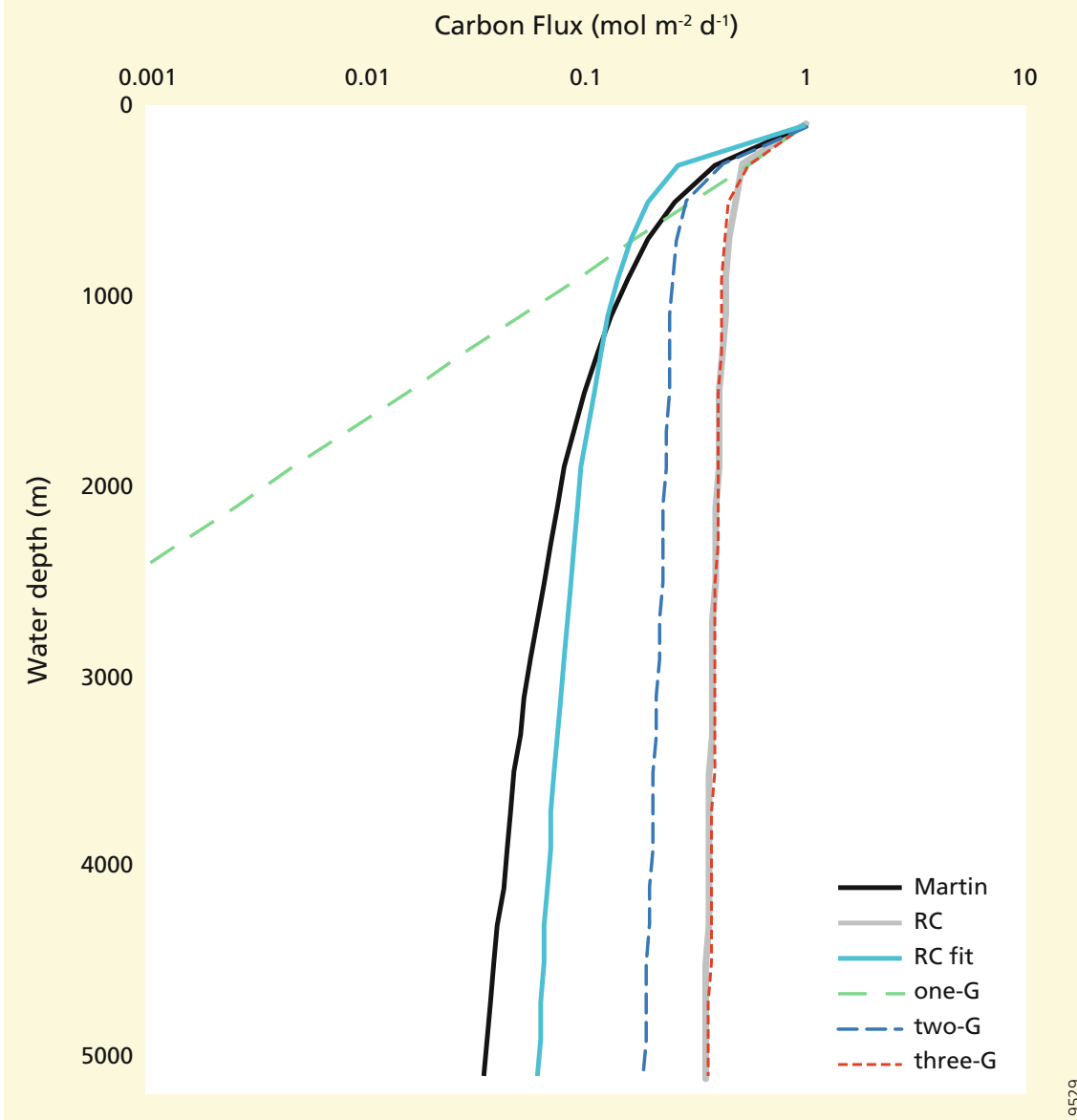

Fig. 3.5 Fluxes of particulate organic carbon in the ocean interior based on the Martin curve and model predictions using different parameterisation for organic matter degradation. The one-G has a fixed $k$ of $0.03\left(\mathrm{~d}^{-1}\right)$, the three G-model and reactive continuum (RC) parameters were taken from Boudreau and Ruddick (1991), the two G-model has similar k parameterisation as the three-G model but without a refractory fraction. The RC fit curve was based on fitting parameter $v$ to the Martin curve $(v=0.59)$. Such a high $v$ implies a dominance of fresh material

by the balance between gravitational acceleration of the particle $(g \times \Delta \rho)$ and the drag acting upon it via surface area $\left(\mathrm{r}^{2}\right)$ and the friction of the fluid $(\mu)$. Particle size and density are the crucial factors (Sarmiento and Gruber 2006). The density difference $\Delta \rho$ is much larger for calcite and clay minerals with densities of $\sim 2700$ $\mathrm{kg} \mathrm{m}^{-3}$ than for organic matter with a density of $\sim 1060 \mathrm{~kg} \mathrm{~m}^{-3}$, a little higher than that of water $\sim 1027 \mathrm{~kg} \mathrm{~m}^{-3}$. An organic particle with a diameter of $100 \mu \mathrm{m}$ will settle $\sim 12 \mathrm{~m} \mathrm{~d}^{-1}$, while a pure calcite or clay mineral particles will sink $\sim 600 \mathrm{~m} \mathrm{~d}^{-1}$. Decreasing the size of the particle by a factor 10 lowers sinking 
velocities by a factor 100 , because of the $r^{2}$ dependence, indicating that small reactive organic particles will never reach the seafloor.

Although Stokes' law is based on physical principles and generally valid, application to particles in the ocean is not straightforward. Particles are diverse and made up of aggregates of various plankton types, their detritus, faecal pellets and different mineral phases with distinct densities. Stokes' law as formulated above is for spherical particles and most marine particles, organism and their remains may deviate strongly from this shape, with the consequence that they are somewhat less dependent on size. Moreover, particles sizes in the ocean vary over orders of magnitude. Size spectra analysis show that most mass occurs in the smaller size classes and cannot directly be linked to that of primary producers size spectra. During settling, particles interact, disaggregate and coagulate, with the consequence that the number and size distribution of particles changes. Natural organic matter aggregates have high porosity, which decreases the density difference between water and particles and thus gravitational acceleration. Nevertheless, settling velocities of natural particles have shown to follow a power law with particle size (Clegg and Whitfield 1990; Sarmiento and Gruber 2006). In situ settling velocities have been quantified by high-resolution underwater video systems and inferred from the time-lag of pulse arrival between sediment traps at different water depth in the same area. The latter approach showed that particle settling velocities increased with depth (Berelson 2002).

To explore the impact of increasing settling velocities a linear and exponential increase of particle sinking rates with water depth was assumed (Fig. 3.6b) and Eq. 3.5 solved for these situations (Fig. 3.6a). A linear increasing rate of particle settling from $10 \mathrm{~m} \mathrm{~d}^{-1}$ at the bottom of the euphotic zone to about $185 \mathrm{~m}$, combined with a first-order degradation rate constant $\left(\mathrm{k}=0.03 \mathrm{~d}^{-1} ; \sim 11 \mathrm{y}^{-1}\right)$ agrees with the parameterisation of Suess (1980) and Martin et al. (1987). Evidently the initial assumption of constant first-order rate constants and sinking velocities might be questionable.

These agreements between the Martin's ocean composite model and the reactive continuum (with high $v$ ) and linear increasing settling rates are not unexpected: it is in the equations. The flux equation for the reactive continuum model with uniform w:

$$
F_{z}=F_{0}\left(\frac{a w}{a w+z}\right)^{v}
$$

approaches the Martin et al. curve if aw $<<$ z. Similarly, the flux equation for constant reactivity but with linear increasing velocity according to $\mathrm{wz}=\mathrm{c} \mathrm{z}$ (c in $\left.\mathrm{d}^{-1}\right)$ is:

$$
F_{z}=F_{0}\left(\frac{z}{z_{0}}\right)^{\frac{-k}{c}}
$$




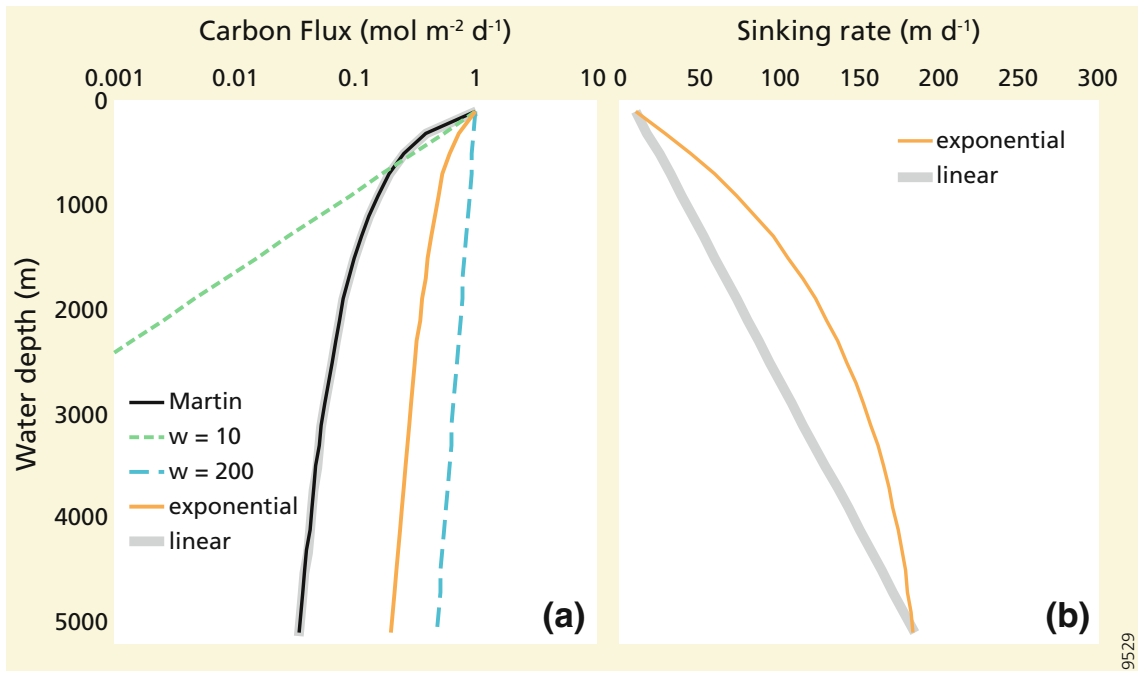

Fig. 3.6 a Fluxes of particulate organic carbon in the ocean interior based on the Martin curve and model predictions using different parameterisation for particle sinking rates. b Parameterisation for particle sinking rates in the ocean used to generate panel a. The solution to Eq. 3.5 with an exponentially increasing sink rate $\mathrm{w}=\mathrm{v}_{0}+\mathrm{v}_{1} \mathrm{e}^{-\mathrm{bz}}$ is: $\mathrm{F}_{\mathrm{z}}=\mathrm{F}_{\mathrm{z}_{0}} \mathrm{e}^{\frac{-\mathrm{k}}{v_{0}}\left(\mathrm{z}-\mathrm{z}_{0}\right)}\left(\frac{v_{0}+v_{1} \mathrm{e}^{-\mathrm{b}\left(\mathrm{z}-\mathrm{z}_{0}\right)}}{v_{0}+v_{1}}\right)^{\frac{-\mathrm{k}}{v_{0}} \mathrm{~b}}$ and with a linear increasing sink rate $\mathrm{w}=\mathrm{c} \mathrm{z}$, it is: $\mathrm{F}_{\mathrm{z}}=\mathrm{F}_{\mathrm{z}_{0}}\left(\frac{\mathrm{z}}{\mathrm{Z}_{0}}\right)^{\frac{-\mathrm{k}}{\mathrm{c}}}$

which returns Martin's power law if $\frac{-k}{c}$ is -0.858 . With a $\mathrm{k}$ value of $0.03 \mathrm{~d}^{-1}(11$ $\mathrm{y}^{-1}$ ), settling velocities should then increase with a $\mathrm{c}$ value of 0.035 from 10 to about $185 \mathrm{~m} \mathrm{~d}^{-1}$ in the deep ocean, within the range of observed values (Berelson 2001).

Most of our knowledge of the nature, dynamics and magnitude of vertical organic particle fluxes in the ocean interior is based on sediment traps, which are one-side open vertical cylinders or conical containers that are fixed to a mooring or floating. These data may be biased because of hydrodynamics, degradation of material in the trap before recovery, and collection of swimming, foraging animals that are killed while feeding on the poisoned traps (Sarmiento and Gruber 2006).

An alternative approach to quantify the depth attenuation of particulate organic carbon fluxes in the ocean involves the use of sediments as the ultimate sediment trap. The idea is that eventually all organic material arriving at the seafloor is respired and can be measured by sediment oxygen uptake (the rationale for this approach will be explained in Chap. 4). Our mass-balance approach is shown in Fig. 3.7. Assuming that sediment respiration at a particular depth reflects the particulate organic carbon flux at that depth at any place in the ocean, we can calculate the total organic carbon flux as a function of depth by using the total area of the ocean at that depth. In other words, we assume a lateral homogenous ocean with no gradients in export between coastal and open ocean systems and between 


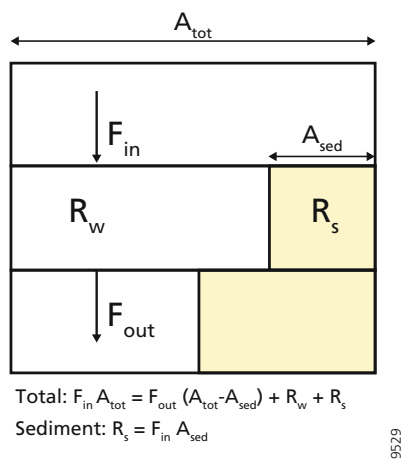

Fig. 3.7 Schematic picture for the carbon balance for a depth layer in the interior ocean. The incoming flux of settling carbon $\left(\mathrm{F}_{\mathrm{in}}\right)$ over the total surface area $\left(\mathrm{A}_{\text {tot }}\right)$ of the ocean is balanced by the flux of carbon passing by $\left(\mathrm{F}_{\text {out }}\right)$ for the total surface area minus that of sediments $\left(\mathrm{A}_{\text {sed }}\right)$ and the carbon that is respired in the water column $\left(\mathrm{R}_{\mathrm{w}}\right)$ and in the sediment $\left(\mathrm{R}_{\mathrm{s}}\right)$. Moreover, sediment carbon respiration equals incoming flux $\left(\mathrm{F}_{\mathrm{in}}\right)$ times global sediment area $\left(\mathrm{A}_{\text {sed }}\right)$ at that depth

high-latitude and low-latitude systems. Sediment oxygen consumption data of Andersson et al. (2004) were fitted with a power law and combined with ocean hypsometry (ETOP1) data. Moreover, by differencing carbon fluxes between two depth layers, we obtain total respiration in that depth zone. By substracting sediment respiration from total respiration we can derive the water-column respiration. A similar approach can be applied to the Suess and Martin relationships, as already shown by these authors. Water-column respiration rates estimated from sediment oxygen consumption are consistent with respiration rates calculated from the Martin et al. (1987) and Suess (1980) relations (Fig. 3.8), both in terms of profile shape, as well as magnitude. These are completely independent estimates: the sediment approach is based on sediment oxygen consumption, while the Martin and Suess approaches are based on primary production and sediment trap data. Depth integration of these global respiration versus depth profiles allows calculation of water-column respiration in the ocean interior (Table 3.1). Ocean interior water-column respiration estimates inferred from sediment oxygen consumption are intermediate between those derived from the Martin and Suess relationships (the latter is based on a global primary production of $50 \mathrm{Pg} \mathrm{C} \mathrm{y-}^{1}$ ), and consistent with literature estimates (Dunne et al. 2007). However, part of the settling carbon flux arrives at the ocean floor and this is not included in the Martin and Suess relationship. Total respiration in the ocean interior is, therefore, substantially higher (Table 3.1). While water-column respiration declines systematically with increasing water depth, global sediment respiration rates increase again below 1-2 km because of ocean hypsometry: large parts of the ocean have water depths between 3 and $6 \mathrm{~km}$. As a consequence, at water depths more than $3 \mathrm{~km}$ sediments dominate organic carbon degradation, and thus oxygen consumption and carbon dioxide production (Fig. 3.8) This trend is robust because other sediment oxygen 


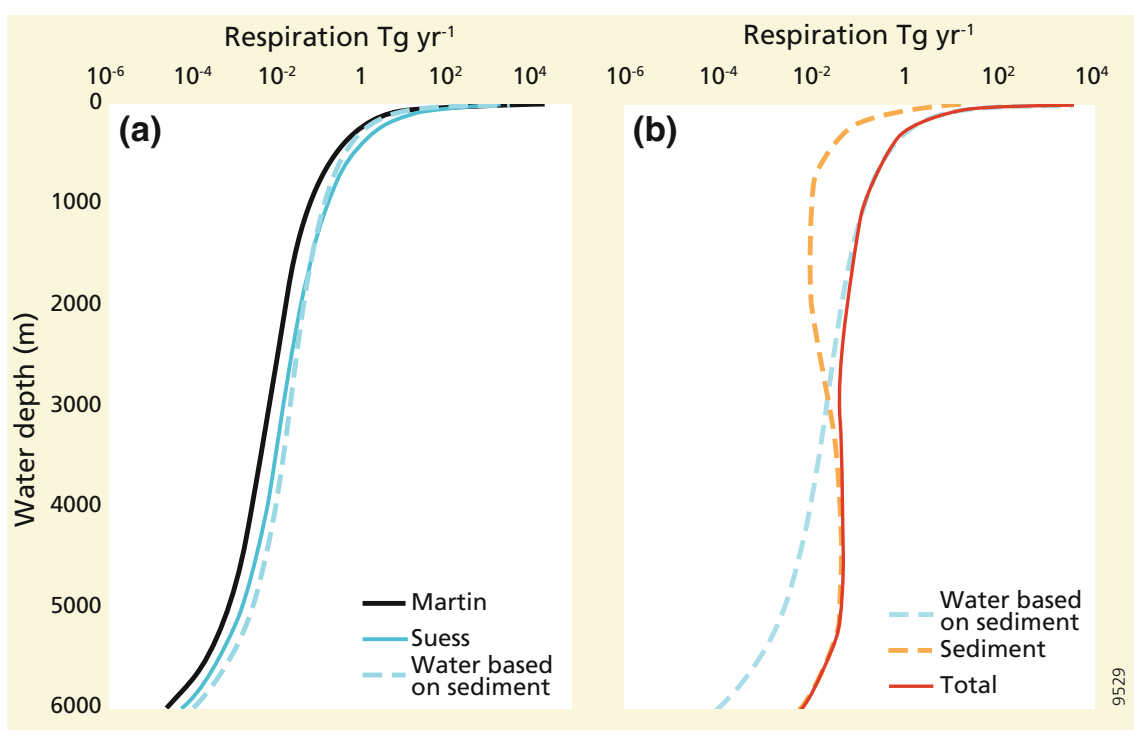

Fig. 3.8 a Water-column respiration in the ocean interior calculated from the Suess and Martin relationships and from sediment oxygen consumption data and the mass balance model of Fig. 3.7. 10 b Depth distribution of total respiration, water-column and sediment respiration based on a power fit to the Andersson et al. (2004) data. Sediment respiration dominates at water depths more than $3000 \mathrm{~m}$ because of hypsometry of the ocean. The Martin relations for respiration: $R_{w}=$ $13.1\left(\frac{\mathrm{Z}}{100}\right)^{-1.858}$. The Suess flux relation $\mathrm{F}_{\mathrm{z}}=\frac{\mathrm{F}_{\mathrm{z}_{0}}}{(0.0238 \mathrm{Z}+0.212)}$ was combined with a global net primary production of $50 \mathrm{Pg} \mathrm{C} \mathrm{y}^{-1}$. Sediment data are from Andersson et al. (2004) and were fit with a power law: $\mathrm{F}_{\mathrm{z}}=84.88(\mathrm{z})^{-0.54}\left(\mathrm{mmol} \mathrm{C} \mathrm{m}^{-2} \mathrm{~d}^{-1}\right)$

Table 3.1 Respiration in the ocean interior $\left(\mathrm{Pg} \mathrm{C} \mathrm{y}^{-1}\right)$

\begin{tabular}{|l|l|l|l|l|l|l|} 
& $\begin{array}{l}\text { Water } \\
\text { column } \\
\text { Martin }^{\mathrm{a}}\end{array}$ & $\begin{array}{l}\text { Water } \\
\text { column } \\
\text { Suess }^{\mathrm{b}}\end{array}$ & $\begin{array}{l}\text { Water } \\
\text { column } \\
\mathrm{Rw}^{\mathrm{c}}\end{array}$ & $\begin{array}{l}\text { Sediment } \\
\mathrm{Rs}^{\mathrm{c}}\end{array}$ & $\begin{array}{l}\text { Total } \\
\text { respiration }\end{array}$ & $\begin{array}{l}\text { Total } \\
\text { Glud }^{\mathrm{d}}\end{array}$ \\
\hline $100 \mathrm{~m}$ & 5.85 & 17.40 & 8.79 & 1.77 & 10.56 & 14.07 \\
\hline $100 \mathrm{~m}$ & 3.05 & 8.64 & 5.53 & 1.59 & 7.12 & 8.26 \\
\hline $1000 \mathrm{~m}$ & 0.55 & 1.35 & 1.48 & 1.38 & 2.86 & 2.40 \\
\hline $2000 \mathrm{~m}$ & 0.19 & 0.45 & 0.60 & 1.26 & 1.86 & 1.36 \\
\hline
\end{tabular}

${ }^{a}$ Water column respiration based on Martin et al. (1987)

${ }^{\mathrm{b}}$ Water column respiration based on Suess (1980) and global primary production of $50 \mathrm{Pg} \mathrm{C} \mathrm{y}^{-1}$ ${ }^{\mathrm{c}}$ Total, sediment and water column respiration based on Andersson et al. (2004) data and approach outlined in Fig. 3.8

${ }^{\mathrm{d}}$ Total respiration based on Glud (2008) sediment data and same as approach as for Andersson et al. (2004) data

consumption versus water depth curves generate similarly shaped curves and benthic contribution to deep-sea respiration (Table 3.1). Clearly, a more detailed look at sediment carbon processing is warranted, and this is provided in the Chap. 4. 


\section{Box 3.1: Organic matter reactivity}

Detrital organic matter represents a very heterogeneous pool of thousands of organic compounds. Individual compounds may originate from various organisms, come from different environments, may have been produced recently or thousands of years ago, and have experienced a different history before eventually making up the compound pool of dissolved or particulate organic matter. Moreover, for particulate organic matter these compounds may be associated with different mineral phases or incorporated in various ways into minerals (Arndt et al. 2013). All these factors and intrinsic differences in reactivity among organic compounds result in large differences in organic matter reactivity (Middelburg 1989). Organic matter reactivity is usually expressed in terms of a first-order rate constant $(\mathrm{k})$, which originates from the one-G model of marine organic matter degradation (Berner 1964):

$$
\frac{d G_{m}}{d t}=-k G_{m}
$$

where $\mathrm{G}_{\mathrm{m}}$ is the concentration of metabolizable organic matter, $\mathrm{t}$ is time and $\mathrm{k}$ is a first-order rate constant $\left(\right.$ time $\left.^{-1}\right)$ assumed to be constant in time. This equation implies that the concentration $\left(\mathrm{G}_{\mathrm{m}}\right)$ and rate $\frac{d G_{m}}{d t}$ decrease exponentially with time. This model has been used successfully in various environments, from soils to sediments, from algal decomposition experiments to sewage degradation. However, there are two issues with its use (Middelburg 1989). One, it assumes that we know a priori the partitioning between refractory organic matter $\left(G_{r}\right)$ and degradable organic matter $\left(G_{m}\right)$ that add up to the total concentration $(\mathrm{G})$. Two, organisms have been shown to preferentially utilize organic substrates, the more reactive being consumed first. This has a few consequences: the reactivity of the remaining organic matter decreases with reaction progress, i.e. time, and there are systematic changes in the composition of organic matter (Dauwe et al. 1999; Chap. 6).

To account for the observed decline in reactivity of organic matter with time, two alternative approaches have been presented: the multi-G and reactive continuum models. The multi-G model (Jørgensen 1978; Westrich and Berner 1984) divides the organic matter pool into a discrete number of fractions (usually two reactive and one refractory) with a different reactivity, each of which undergoes first-order decay. The relevant equations are:

$$
\begin{gathered}
G=\sum_{i} G_{i} \\
\frac{d G_{i}}{d t}=-k_{i} G_{i}
\end{gathered}
$$




$$
\frac{d G}{d t}=-\sum_{i} k_{i} G_{i}
$$

where $G_{i}$ is the concentration of organic carbon in each group $i, k_{i}$ is the first-order reactivity of each group and $i>1$. The one-G model (Eq. 3.11) is an example where $\mathrm{i}=2$, one labile class and one refractory group (with a $\mathrm{k}_{\mathrm{i}}$ of zero). Selective removal according to the reactivity of each group accounts for the decrease in reactivity, amount and rate of organic matter degradation. However, successful application of this model requires knowledge on the number of labile groups, their contribution and their reactivity. These are unknown and cannot be measured.

The reactive continuum models do not subjectively partition organic matter into a number of pools but consider reactivity as an emergent property of the total organic matter pool that continuously declines as reaction progresses with time (Middelburg 1989). The two most commonly used models are the semi-empirical power model (Middelburg 1989):

$$
\frac{d G}{d t}=-k(t) G
$$

where $G$ is the total pool of organic matter and $k(t)$ is time-dependent first-order rate constant, and the gamma-distribution reactive continuum model (Boudreau and Ruddick 1991):

$$
\frac{d G}{d t}=-k_{m} G^{1+\frac{1}{v}}
$$

where $\mathrm{G}$ is again the total pool of organic carbon, $v$ is a parameter for the shape of the underlying Gamma distribution and $k_{m}=\frac{v}{a G_{0}^{v}}$ is the apparent rate constant for the mixture: $a$ is a measure for average lifetime of the most reactive component and $\mathrm{G}_{0}$ is the initial concentration of organic carbon. Moreover, reformulated in a closed form:

$$
G=G_{0}\left(\frac{a}{a+t}\right)^{v},
$$

it describes the evolution of organic matter as a function of time (Boudreau and Ruddick 1991). The power and gamma-type reaction continuum model are under certain conditions equivalent and both are particular cases of the general q-theory of Bossata and Agren (1995). Although these continuum models are less used than the discrete models (Arndt et al. 2013), they have been applied for particulate organic matter in soils, sediments and suspended particles, phytoplankton degradation experiments and dissolved organic matter degradation in lakes. Apparent reactivity constants vary over 8 orders 


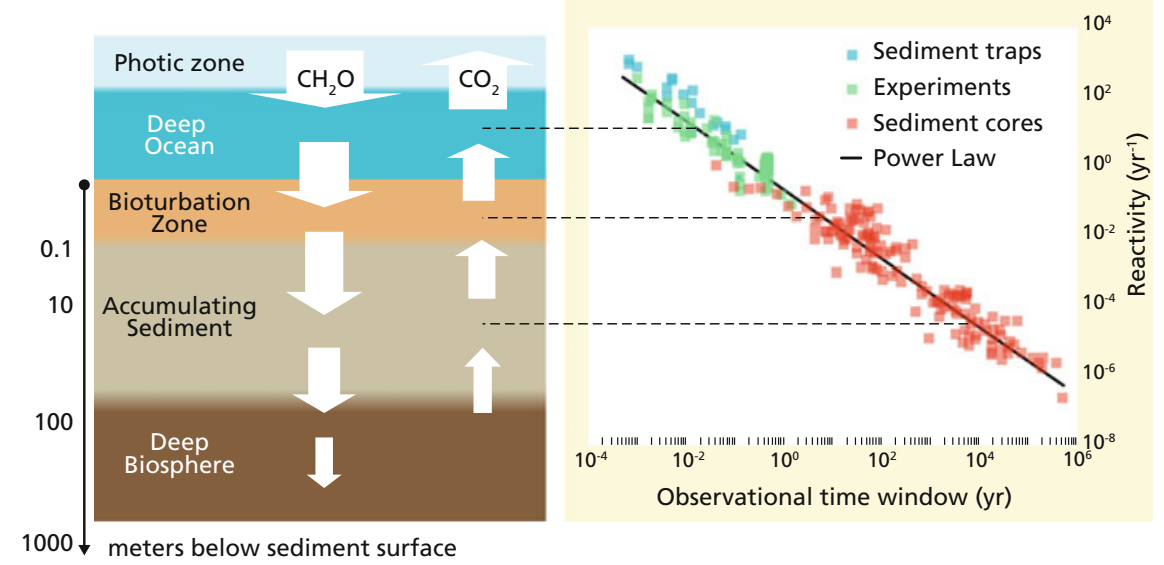

Fig. 3.9 The reactivity of particulate organic matter is an emergent property that decreases with the accumulated time period since it became detritus. Reactivity estimates are based on phytoplankton degradation experiments, settling phytoplankton and sediments in the accumulated zone. A power law $\left(\mathrm{k}=0.21 \mathrm{t}^{-0.985}\right)$ relates $\mathrm{k}$ the first-order kinetic coefficient $\left(\mathrm{yr}^{-1}\right)$ with time (t) in yr (Middelburg 1989; Middelburg and Meysman 2007). Fresh phytoplankton initially has a high reactivity and this reactivity decreases during degradation because of preferential degradation, secondary production and mixing with more refractory components

of magnitude (Fig. 3.9), and we unfortunately lack analytical protocols to measure it directly or indirectly via a proxy. As a consequence, organic matter reactivity is a poorly constrained parameter in all biogeochemical models.

\section{Box 3.2: Carbon consumption in the coastal ocean}

In coastal zone, organic carbon is not only newly produced by phytoplankton, but also by microphytobenthos, macroalgae, seagrass, marshes and mangroves and imported from terrestrial ecosystems. Duarte and Cebrian (1996) presented the fate of autotrophic carbon based on an extensive cross-system survey (Fig. 3.10). Autotrophic respiration represents a loss of 26-35\% for phytoplankton and microphytobenthos, while marine vegetations respire between 51 and $69 \%$ of their gross primary production. Herbivory losses are much higher for phytoplankton and microphytoplankton (26-37\%), than for seagrass, marshes and mangroves (4-10\%) with macroalgae in between $(\sim 16 \%)$. Detritus production and respiration were similar among these communities (15-27\% of GPP) with the balance of organic material being exported to adjacent systems. These cross-system patterns in autotrophic respiration can be partly attributed to differences in biomass relative to production, because autotrophic respiration scales with biomass (Soetaert and 


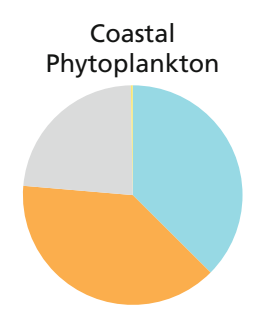

Microphytobenthos

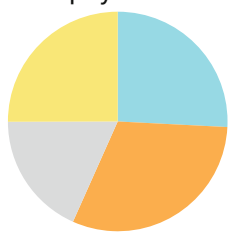

Ocean

Phytoplankton
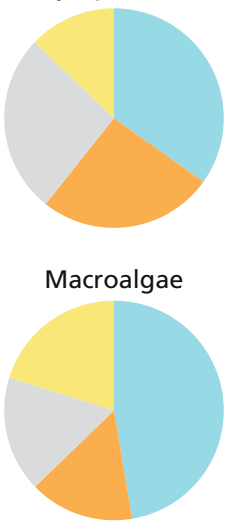

Seagrass

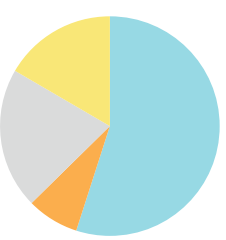

Marsh plants

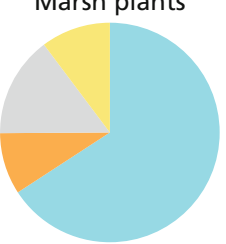

Mangroves

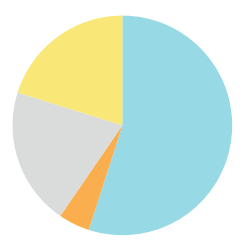

Fig. 3.10 Fate of primary produced materials for marine communities. Blue: autotrophic respiration, orange: herbivory; grey: degradation; yellow: export \& accumulation (Duarte and Cebrian 1996)

Herman 2009). Differences in herbivory losses between phytoplankton and microphytobenthos on the one hand and higher plants on the other can be attributed to the general decline in growth rate and palatability and nutrient availability from microalgae to higher plants (Duarte and Cebrian 1996). The palatability of phytoplankton and microphytobenthos is generally much higher than that of terrestrial and littoral plants (mangroves, salt marshes) because the latter have lower nutrient and protein contents, higher proportions of structural components such as carbohydrates and lignins needed for rigidity and sometimes chemical compounds for defences. Grazers on seagrass and salt-marsh plants consequently have different feeding and digestion strategies than those on phytoplankton and microphytobenthos. While waterfowl, turtles and mammals such as the dugong are iconic grazers of seagrasses, many other organisms such as gastropods, isopods and sea urchins feed on epiphytes, the microbes growing on the leaves of seagrass. These epiphytes function more alike phytoplankton and microphytobenthos in terms of productivity, turn-over and their fate.

Herbivory represents a major loss pathway for phytoplankton and involves zooplankton as well as benthic suspension feeders. While benthic and pelagic grazers have many commonalities, there are also distinct differences: benthic suspension feeders are normally sessile, while planktonic float; benthic suspension feeders are usually larger and longer-lived with the consequence that they overwinter and already have a high biomass before the phytoplankton 
spring bloom. Moreover, benthic suspension feeders have only access to phytoplankton in the lower part of the water column and vertical mixing is an important factor governing their growth and their impact on phytoplankton dynamics (Herman et al. 1999).

Coastal systems exchange organisms and detrital material with adjacent ecosystems and receive detrital resources via rivers. This additional external organic matter is consumed and, as a consequence, the local balance between autotrophic and heterotrophic processes is disturbed, with net ecosystem heterotrophy as a result (Smith and Hollibaugh 1993). Heterotrophic ecosystems often show secondary production, similar to or higher than primary production, a dominance of microbial processes, a depletion in dissolved oxygen, and high carbon dioxide levels (Heip et al. 1995).

\section{References}

Anderson TR, LeB Williams PJ (1998) Modelling the seasonal cycle of dissolved organic carbon at station E1 in the English channel. Estuar Coast Shelf Sci 46:93-109

Andersson H, Wijsman JWM, Herman PMJ, Middelburg JJ, Soetaert K, Heip C (2004) Respiration patterns in the deep ocean. Geophys Res Lett 31. https://doi.org/10.1029/ $2003 \mathrm{gl} 1018756$

Arndt S, Jørgensen BB, LaRowe D, Middelburg JJ, Pancost R, Regnier P (2013) Quantification of organic matter degradation in marine sediments: a synthesis and review. Earth Sci Rev 123:5386

Azam F, Fenchel T, Field JG, Gray JS, Meyer-Reil LA, Thingstad F (1983) The ecological role of water-column microbes in the sea. Mar Ecol-Prog Ser 10:257-263

Berelson W (2001) POC fluxes into the ocean interior: a comparison of 4 US-JGOFS regional studies. Oceanography 14:59-67

Berelson WM (2002) Particle settling rates increase with depth in the ocean. Deep Sea Res II, 49:237-251

Berner RA (1964) An idealized model of dissolved sulfate distribution in recent sediments Geochimica et Cosmochimica Acta 28:1497-1503

Bossata E, Ågren GI (1995) The power and reactive continuum models as particular cases of the q-theory of organic matter dynamics. Geochimica et Cosmochimica Acta 59:3833-3835

Boudreau BP, Ruddick BR (1991) On a reactive continuum representation of organic matter diagenesis. Am J Sci 291:507-538

Clegg SL, Whitfield M (1990) A generalized model for the scavenging of trace metals in the open ocean. I.-Particle cycling. Deep-Sea Res 37:809-832

Dauwe B, Middelburg JJ, Herman PMJ, Heip CHR (1999) Linking diagenetic alteration of amino acids and bulk organic matter reactivity. Limnol Oceanogr 44:1809-1814

Duarte CM, Cebrian J (1996) The fate of marine autotrophic production. Limnol Oceanogr 41:1758-1766

Dugdale RC, Goering JJ (1967) Uptake of new and regenerated forms of nitrogen in primary productivity. Limnol Oceanogr 12:196-206 
Dunne JP, Sarmiento JL, Gnanadesikan A (2007) A synthesis of global particle export from the surface ocean and cycling through the ocean interior and on the seafloor. Glob Biogeochem Cycles 21:GB4006. https://doi.org/10.1029/2006gb002907

Dunne JP, Armstrong RA, Gnanadesikan A, Sarmiento JL (2005) Empirical and mechanistic models for the particle export ratio. Global Biogeochem Cycles 19:GB4026. https://doi.org/10. 1029/2004gb002390

Field CB, Behrenfeld MJ, Randerson JT, Falkowski PG (1998) Primary production of the biosphere: integrating terrestrial and oceanic components. Science 281:237-240

Glud RN (2008) Oxygen dynamics of marine sediments. Mar Biol Res 4:243-289

Heip CHR, Goosen NK, Herman PMJ, Kromkamp J, Middelburg JJ, Soetaert K (1995) Production and consumption of biological particles in temperate tidal estuaries. Oceanogr Mar Biol Ann Rev 33:1-150

Herman PMJ, Middelburg JJ, van de Koppel J, Heip CHR (1999) Ecology of estuarine macrobenthos. Adv Ecol Res 29:195-240

Jørgensen BB (1978) A comparison of methods for the quantification of bacterial sulfate reduction in coastal marine sediments. II. Calculation from mathematical models. Geomicrobiol J 1:29_ 47

Laws EA, D'Sa E, Puneeta N (2011) Simple equations to estimate ratios of new or export production to total production from satellite-derived estimates of sea surface temperature and primary production. Limnol Oceanogr Methods 9. https://doi.org/10.4319/lom.2011.9.593

Laws EA, Falkowski PG, Smith WO, Ducklow H, McCarthy JJ (2000) Temperature effects on export production in the open ocean. Glob Biogeochem Cycles 14:1231-1246

Legendre L, Rassoulzadegan F (1995) Plankton and nutrient dynamics in marine waters. Ophelia 41:153-172

Lutz M, Dunbar R, Caldeira K (2002) Regional variability in the vertical flux of particulate organic carbon in the ocean interior. Glob Biogeochem Cycles 16:1037. https://doi.org/10.1029/ 2000GB001383

Martin JH, Knauer GA, Karl DM, Broenkow WW (1987) VERTEX: carbon cycling in the Northeast Pacific. Deep Sea Res 34:267-285

Middelburg JJ (1989) A simple rate model for organic-matter decomposition in marine sediments. Geochim Cosmochim Acta 53:1577-1581

Middelburg JJ, Meysman FJR (2007) Burial at sea. Science 317:1294-1295

Pace ML, Cole JJ, Carpenter SR, Kitchell JF (1999) Trophic cascades revealed in diverse ecosystems. Trends Ecol Evol 14:483-488

Pace ML, Knauer GA, Karl DM, Martin JH (1987) Primary production, new production and vertical flux in the Eastern Pacific Ocean. Nature 325:803-804

Sarmiento J, Gruber N (2006) Ocean biogeochemical dynamics. Princeton University Press, Princeton, p 526

Smith SV (1981) Marine macrophytes as a global carbon sink. Science 211:838-840

Smith SV, Hollibaugh JT (1993) Coastal metabolism and the oceanic organic carbon balance. Rev Geophys 31:75-89

Soetaert K, Herman PMJ (2009) A practical guide to ecological modelling. Springer, Netherlands, p 372

Suess E (1980) Particulate organic carbon flux in the oceans-surface productivity and oxygen utilization. Nature 288:260-263

Suttle CA (2005) Viruses in the sea. Nature 437:356-361

Van den Meersche K, Middelburg JJ, Soetaert K, van Rijswijk P, Boschker HTS, Heip CHR (2004) Carbon-nitrogen coupling and algal-bacterial interactions during an experimental bloom: modeling a 13C tracer experiment. Limnol Oceanogr 49:862-878 
Volk T, Hoffert MI (1985) Ocean carbon pumps: analysis of relative strengths and efficiencies in ocean-driven atmospheric $\mathrm{CO}_{2}$ change. In: Sundquist ET, Broecker WS (eds) The Carbon cycle and atmospheric $\mathrm{CO}_{2}$ : natural variations Archean to present. AGU, Washington, pp 99 110

Westrich JT, Berner RA (1984) The role of sedimentary organic matter in bacterial sulfate reduction: the G model tested. Limnol Oceanogr 29:236-249

Yamanaka Y, Tajika E (1996) The role of the vertical fluxes of particulate organic matter and calcite in the oceanic carbon cycle: studies using an ocean biogeochemical general circulation model. Global Biogeochem Cycles 10:361-382

Open Access This chapter is licensed under the terms of the Creative Commons Attribution 4.0 International License (http://creativecommons.org/licenses/by/4.0/), which permits use, sharing, adaptation, distribution and reproduction in any medium or format, as long as you give appropriate credit to the original author(s) and the source, provide a link to the Creative Commons licence and indicate if changes were made.

The images or other third party material in this chapter are included in the chapter's Creative Commons licence, unless indicated otherwise in a credit line to the material. If material is not included in the chapter's Creative Commons licence and your intended use is not permitted by statutory regulation or exceeds the permitted use, you will need to obtain permission directly from the copyright holder.

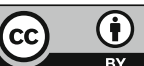

